\title{
EFFECT OF NITROGEN AND SOME WEED CONTROL METHODS ON YIELD AND QUALITY OF ONION IN A NEWLY RECLAIMED SOIL
}

\author{
Ali, Mohamed A.M. ${ }^{*}$ and Ahmed I. El-Tokhy ${ }^{2}$ \\ ${ }^{1}$ Department of Horticulture, Faculty of Agriculture, New Valley \\ University \\ ${ }^{2}$ Department of Plant Protection, Faculty of Agriculture, New Valley \\ University \\ *E-mail: mohamedahmedali77@aun.edu.eg
}

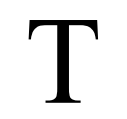

wo field experiments were carried out during the two successive winter seasons of 2014/2015 and 2015/2016, at the Farm of the Faculty of Agriculture, New Valley University, to study the effect of four rates of mineral nitrogen fertilizer, i.e., $0,178.60,357.14$ and $535.71 \mathrm{~kg} \mathrm{~N} \mathrm{ha}^{-1}$ and three weed control methods, i.e., unweeding, hand weeding and chemical herbicides, i.e., bentazon (Basagran ${ }^{\circledR} 48 \%$ AS) and clethodium (Select super ${ }^{\circledR} 12.5 \% \quad$ EC) at the recommended rates $(1.19$ $\mathrm{L} / 238 \mathrm{~L} / \mathrm{ha}$ and $0.595 \mathrm{~L} / 238 \mathrm{~L} / \mathrm{ha}$, respectively) on yield and bulb quality of onion cv. Giza 6 . The obtained results showed that the interaction from mineral nitrogen at the highest rate $\left(535.71 \mathrm{~kg} \mathrm{~N}^{-}\right.$ $\left.{ }^{1}\right)$ and hand weeding method significantly increased the percentages of bulbs ranged from 6-8 $\mathrm{cm}$ in diameter, doubles, bulb fresh weight $(\mathrm{g})$, bulb diameter and length $(\mathrm{cm})$, bulb dry matter $(\%)$, bulb quality such as vitamin $\mathrm{C}$ concentration, percentages of sulfur volatile oil, total soluble solids (TSS), crude protein and total carbohydrates in onion bulb. On the other hand, the percentages of bulbs ranged from $3.5-6 \mathrm{~cm}$ in diameter, bolters and pickles were the highest with the interaction between unfertilized and unweeding plants in both growing seasons. In this regard, the interaction between the highest rate of nitrogen $\mathrm{ha}^{-1}$ and hand weeding method significantly increased yield ha $^{-1}$. In addition, the highest values of yield due to the interaction between the highest rate of nitrogen ha ${ }^{-1}$ and hand weeding method were 12.59 and 13.51 ton $\mathrm{ha}^{-1}$, when compared to the interaction between unfertilized and unweeding plants (4.29 and 4.19 ton $\mathrm{ha}^{-1}$ ) in both growing seasons, respectively.

Keywords: Allium cepa, nitrogen, hand weeding, herbicides, yield, volatile oil 
Onion (Allium cepa L.) belongs to the family of Alliaceae. In Egypt, onion is one of the major and popular vegetable crops; it is considered the third most important vegetable crop after tomato and potato. The volatile flavors of onion increased its consumptions rate worldwide (Abbey and Joyce, 2004). Additionally, several medical constituents presented in the onion tissues are used for the therapy of several diseases (Martinez et al., 2007 and Stajner et al., 2008). During 2014 season, the total harvested area in Egypt amounting to 68487 ha, produced about 2505189 ton with an average of 36.58 ton of dry onions/ha (FAOSTAT, 2015).

Onion is one of the major vegetable cultivated in the New Valley Governorate, and there is a continuous need for applying nitrogen fertilizers to overcome the infertility problems of soil.

The New Valley Governorate is located in the south-west of Egypt's Western Desert; most where newly reclaimed sand soils are characterized by low organic matter and nutrients contents.

Nitrogen is considered the major element in plant tissues with average percentage of $7 \%$ of total dry matter of plants and is a constituent of many fundamental cell components and plays an important role for increasing crop production (Marschner, 1995 and Bungard et al., 1999).

Several researchers showed that increasing nitrogen fertilizer's levels led to increase yield and its components and bulb onion quality (Rizk, 1997; Tiwori et al., 2002; Abdel-Mawgoud et al., 2005; Khan et al., 2007; Nasreen et al., 2007; Al-Fraihat, 2009; Rizk et al., 2012; Soleymani and Shahrajabian, 2012; El-Hadidi et al., 2016 and Gebretsadik, 2016). In this regard, El-Hamady (2017) showed that the highest rate of nitrogen fertilizer $(216 \mathrm{~kg} \mathrm{~N} / \mathrm{ha}$ ) gave the highest values of plant height, number of leaves/plant, leaves fresh weight/plant, bulbing ratio, bulb diameter and length, bulb fresh weight, total fresh bulb yield, marketable bulb yield and total soluble solids (TSS) \% in bulbs than other rates of nitrogen fertilizer.

One of the major problems in agricultural production is the spread of weeds, which affect the growth and quality of the growing crops. Onion plant is characterized by slow growth, shallow roots and lack of adequate foliage. Therefore, onion crop cannot compete well with weeds. Consequently, farmers tend to combat weeds by using several ways to achieve high production of onion; especially, in a newly reclaimed soil with low fertility characteristics.

Herbicides are common compounds (chemical-organic) used to eliminate weeds growth (Ramalingam et al., 2013). Several types of herbicides are used extensively to combat weeds, and may contaminate the growing plants (Albero et al., 2001).

In this concern, Uygur et al. (2010) found that weed-free check caused $76.3 \%$ increase in the onion yields, when compared with weedy checks. So the aim of this study is to optimize the production of onion cv. Giza 6 and its quality through application of nitrogen fertilizer rates, beside combating 
weeds through hand weeding and chemical herbicides.

\section{MATERIALS AND METHODS}

\section{Description of the Study Site}

The study soil is located in the Farm of the Faculty of Agriculture, New Valley University. Two field experiments were conducted from October to April of 2014/2015 and 2015/2016 growing seasons. The soil is very poor in its nutritive as well as its organic matter contents (Abdelhafez et al., 2016).

\section{Soil Analysis}

Results of the initial soil analysis are listed in table (1).

Table (1). Physicochemical characteristics of the study soil.

\begin{tabular}{|c|c|c|c|c|c|c|c|c|c|c|c|c|}
\hline \multirow{3}{*}{$*$ pH } & \multirow{3}{*}{$\begin{array}{c}\dagger \mathbf{E C}, \\
\left(\mathbf{d S} \mathbf{~ m}^{-\mathbf{1}}\right)\end{array}$} & \multirow{3}{*}{$\begin{array}{l} \pm \mathrm{OM}, \\
\left(\mathrm{g} \mathrm{kg}^{-1}\right)\end{array}$} & \multicolumn{6}{|c|}{ Nutrient content, $\mathrm{mg} \mathrm{kg}^{-1}$} & \multirow{2}{*}{\multicolumn{3}{|c|}{$\begin{array}{c}\text { Particle size distribution } \\
\%\end{array}$}} & \multirow{3}{*}{$\begin{array}{l}\text { Textural } \\
\text { class }\end{array}$} \\
\hline & & & \multirow{2}{*}{$\begin{array}{c}\mathbf{N} \\
\text { Total } \\
\end{array}$} & \multicolumn{2}{|r|}{$\mathbf{P}$} & \multicolumn{3}{|c|}{$\mathbf{K}$} & & & & \\
\hline & & & & Available & Total & Available & Total & Available & Clay & Silt & Sand & \\
\hline $\begin{array}{c}7.97 \\
\pm 0.06\end{array}$ & $\begin{array}{c}0.26 \\
\pm 0.04\end{array}$ & $\begin{array}{l}1.10 \\
\pm 0.2\end{array}$ & $\begin{array}{l}159.60 \\
\pm 11.30\end{array}$ & $\begin{array}{l}29.20 \\
\pm 2.45\end{array}$ & $\begin{array}{l}62.30 \\
\pm 6.74\end{array}$ & $4.66 \pm 0.92$ & $\begin{array}{l}243.00 \\
\pm 13.23\end{array}$ & $\begin{array}{l}154.00 \\
\pm 8.76\end{array}$ & $\begin{array}{c}6.84 \\
\pm 0.48\end{array}$ & $\begin{array}{l}11.24 \\
\pm 0.47\end{array}$ & $\begin{array}{l}81.92 \\
\pm 0.31\end{array}$ & Sand \\
\hline
\end{tabular}

${ }^{*} \mathrm{pH}$, determined in 1:1 soil: water mixture

$\dagger$ EC, determined in 1:1 soil: water mixture

+ OM, Organic matter

\section{Experimental Procedure}

This experiment included 12 treatments, which were the combination between four rates of mineral nitrogen fertilizer, i.e., 0, 178.60, 357.14 and $535.71 \mathrm{~kg} \mathrm{~N} \mathrm{ha}^{-1}$ and three methods of weed control (unweeded, hand weeding and chemical herbicides). These treatments were arranged in a split plot system in a complete randomized block design with four replications. Nitrogen rates were arranged in the main plot, while methods of weed control were arranged in the sub plots. Onion seedlings cv. Giza 6 were planted on $30^{\text {th }}$ and $25^{\text {th }}$ October in 2014 and 2015, respectively, at distance of $10 \mathrm{~cm}$ apart in both sides of water line and harvested on the first week in April 2015 and 2016.

\section{Fertilization}

The fertilization was adopted according to the recommendations of the Ministry of Agriculture, Egypt. $806.50 \mathrm{~kg} \mathrm{ha}^{-1}$ of ordinary super phosphate $\left(15.5 \% \mathrm{P}_{2} \mathrm{O}_{5}\right)$ equals to $125 \mathrm{~kg} \mathrm{P} \mathrm{ha} a^{-1}$, in addition to $119.05 \mathrm{~kg} \mathrm{ha}^{-1}$ of potassium sulphate $\left(48 \% \mathrm{~K}_{2} \mathrm{O}\right)$ equals to $57.14 \mathrm{~kg} \mathrm{~K} \mathrm{ha}^{-1}$ were add to soil during preparation. Ammonium nitrate $(33.5 \% \mathrm{~N})$ was used as a source of nitrogen fertilizer and was applied at rates of 0.0, 533.14, 1066.09 and $1599.13 \mathrm{~kg} \mathrm{ha}^{-1}$ to achieve the rates of $0.0,178.60,357.14$ (recommended) 
and $535.71 \mathrm{~kg} \mathrm{~N} \mathrm{ha}^{-1}$, respectively. The plot area was $30 \mathrm{~m}^{2}$, including five lines with $10 \mathrm{~m}$ length and $0.6 \mathrm{~m}$ distance between two lines. Nitrogen fertilizer was divided into equal four application portions; these additions started after 15 day from transplanting and repeated three times at 15 days intervals as soil application.

\section{Weed Control Methods}

\subsection{Unweeded treatment}

Weeds were allowed to grow freely without any applications of herbicides or hand weeding.

\subsection{Conventional herbicides treatment}

In this treatment the recommended herbicides were used to combat broad leaves weeds by using bentazon (Basagran ${ }^{\circledR} 48 \%$ AS, BASF) at the recommended rate $(1.19 \mathrm{~L} / 238 \mathrm{~L} / \mathrm{ha})$ with a chemical formula [3-isopropyl$1 \mathrm{H}-2,1,3$-benzothiadiazin-4(3H)-one 2,2-dioxide] and narrow leaves weeds by using clethodium (Select super ${ }^{\circledR} 12.5 \%$ EC, Shoura Chemicals) at the recommended rate $(0.595 \mathrm{~L} / 238 \mathrm{~L} / \mathrm{ha})$ with a chemical formula $[2-\{(\mathrm{E})-1-$ [(E)-3-chloroallyloxyimino] propyl\}-5-[2-(ethylthio) propyl]-3hydroxycyclohex-2-enone]. Herbicides applications began after 20 days of transplanting and repeated 2 times 30 days intervals as foliar application for each herbicide.

\subsection{Hand weeding treatment}

This program intended only hand weeding as a common practice for cultural control of Integrated Pest Management (IPM). The practice was performed twice per month. The treatment was adopted continuously for five months.

\section{Measured Parameters}

\subsection{Yield}

At the harvest date, all onion plants of each plot were harvested and cured for 15 days after harvest, weighted and converted to record the following data:
a. Yield (ton ha' ${ }^{-1}$ )
c. Relative yield $(\%)=\frac{\text { Yield of treatment }}{\text { Yield of control }} \times 100$

\subsection{Characteristics of bulb}

The harvested bulbs were separated to marketable and non-marketable yield. Briefly, bulbs with single, homogenized and without any distortions were classified as marketable yield, while bulbs which doubles, bolters, pickles, un-homogenized and with any distortions were classified as nonmarketable yield. Marketable yield was distinguished into;

a. Percentage of bulbs ranged from $3.5-6 \mathrm{~cm}$ in diameter 
b. Percentage of bulbs ranged from $6-8 \mathrm{~cm}$ in diameter

Each of the above mentioned percentages was determined as percentage of the weight of each one of them per plot of the corresponding total weight of marketable yield per plot. Non-marketable yield was differentiated into;

a. Percentage of doubles

b. Percentage of bolters

c. Percentage of pickles (bulbs less than $3.5 \mathrm{~cm}$ in diameter)

Percentage of each of doubles, bolters and pickles was determined by counting the weight of each one of them per plot as percentage of the total weight of non-marketable yield per plot.

Random samples composed of 30 bulbs were taken from each plot at harvesting date to determine the following data:

a. Bulb fresh weight $(\mathrm{g})$, bulb diameter and length $(\mathrm{cm})$ and bulb dry matter $(\%)$

b. Percentage of bulb net weight $=\frac{\text { Bulb fresh weight }}{\text { Whole plant fresh weight }} \times 100$

\subsection{Bulb quality}

Bulb quality parameters such as vitamin $\mathrm{C}$ concentration and total soluble solids (TSS) \% in fresh onion bulbs juice, percentages of sulfur volatile oil and crude protein (calculated by multiplying nitrogen content by the factor 6.25) in bulbs were determined according to the methods described by A.O.A.C. (2000). Total carbohydrates percentage in bulbs was determined according to Hedge and Hofreiter (1962).

\section{Statistical Analysis}

Data were subjected to the statistical analysis of variance according to the method mentioned by Snedecor and Cochran (1980). The treatment means were compared using Duncan's multiple range test at probability of 5\% level according to Duncan (1958).

\section{RESULTS AND DISCUSSION}

\section{Yield}

\subsection{Effect of nitrogen fertilizer rates}

Fertilization of onion plants under newly reclaimed soil with the highest rate of mineral nitrogen $\left(535.71 \mathrm{~kg} \mathrm{~N} \mathrm{ha}^{-1}\right)$ had significantly increased yield ha ${ }^{-1}$ in both growing seasons (Table 2). The increases in yield were about 67.41 and $70.26 \%$ for the highest rate of nitrogen over unfertilized plants in the $1^{\text {st }}$ and $2^{\text {nd }}$ seasons, respectively. This might be attributed to the vital role of nitrogen for enhancing the metabolism and achieving high carbohydrate contents, which increased the bulb weight consequently total yield increased (Khan et al., 2007). These results are 
harmony with these recorded by Aliyu et al. (2007), Yaso and Abdel-Razzak (2007), Rizk et al. (2012) and El-Hadidi et al. (2016), who recorded significant increases in the bulb yield of onion with application of $\mathrm{N}$ fertilizers.

Table (2). Yield of onion plants as affected by nitrogen fertilizer rates, weed control methods and their interaction between them during $2014 / 2015$ and $2015 / 2016$ seasons.

\begin{tabular}{lcccccccc}
\hline & \multicolumn{3}{c}{$\mathbf{2 0 1 4 / 2 0 1 5}$ season } & \multicolumn{5}{c}{$\mathbf{2 0 1 5 / 2 0 1 6}$ season } \\
\cline { 2 - 9 } Treatments & P0 & P1 & P2 & Mean & P0 & P1 & P2 & Mean \\
\hline & \multicolumn{9}{c}{ Yield (ton ha ${ }^{-1}$ ) } \\
N0 & 4.291 & $6.83 \mathrm{~h}$ & $7.49 \mathrm{~g}$ & $6.20 \mathrm{~d}$ & 4.191 & $7.24 \mathrm{~h}$ & $8.03 \mathrm{~g}$ & $6.49 \mathrm{~d}$ \\
N1 & $5.00 \mathrm{k}$ & $9.07 \mathrm{f}$ & $9.33 \mathrm{e}$ & $7.80 \mathrm{c}$ & $4.94 \mathrm{k}$ & $9.49 \mathrm{f}$ & $10.19 \mathrm{e}$ & $8.21 \mathrm{c}$ \\
N2 & $5.27 \mathrm{j}$ & $10.57 \mathrm{~d}$ & $11.47 \mathrm{c}$ & $9.10 \mathrm{~b}$ & $5.66 \mathrm{j}$ & $11.02 \mathrm{~d}$ & $12.24 \mathrm{c}$ & $9.64 \mathrm{~b}$ \\
N3 & $6.38 \mathrm{i}$ & $12.16 \mathrm{~b}$ & $12.59 \mathrm{a}$ & $10.38 \mathrm{a}$ & $6.66 \mathrm{i}$ & $12.97 \mathrm{~b}$ & $13.51 \mathrm{a}$ & $11.05 \mathrm{a}$ \\
Mean & $5.23 \mathrm{c}$ & $9.66 \mathrm{~b}$ & $10.22 \mathrm{a}$ & \multicolumn{9}{c}{ Relative yield (\%) } \\
\hline & $10.36 \mathrm{c}$ & $10.18 \mathrm{~b}$ & $10.99 \mathrm{a}$ & \\
\hline N0 & 100.00 & 159.20 & 174.59 & 100.00 & 100.00 & 172.79 & 191.64 & 100.00 \\
N1 & 116.55 & 211.42 & 217.48 & 125.80 & 117.89 & 226.49 & 243.19 & 126.50 \\
N2 & 122.84 & 246.38 & 267.36 & 146.77 & 135.08 & 263.00 & 292.12 & 148.53 \\
N3 & 148.71 & 283.44 & 293.47 & 167.41 & 158.94 & 309.54 & 322.43 & 170.26 \\
Mean & 100.00 & 184.70 & 195.41 & & 100.00 & 189.92 & 205.03 & \\
\hline
\end{tabular}

Means with the same letters are not significantly differed at $5 \%$ according to Duncan's multiple range test.

$\mathrm{N} 0=0 \mathrm{~kg} \mathrm{~N} \mathrm{ha}^{-1} \& \mathrm{~N} 1=178.60 \mathrm{~kg} \mathrm{~N}^{-1} \& \mathrm{~N} 2=357.14 \mathrm{~kg} \mathrm{~N}^{-1} \& \mathrm{~N} 3=535.71$ $\mathrm{kg} \mathrm{N} \mathrm{ha}^{-1}$.

P0 $=$ Unweeded \& P1 $=$ Chemical herbicides \& P2 = Hand weeding.

\subsection{Effect of weed control methods}

Hand weeding method recorded maximize yield $\mathrm{ha}^{-1}$ than using other weed control methods in both growing seasons (Table 2). The increases in yield were about 95.41 and $105.03 \%$ for hand weeding method than unweeding in the $1^{\text {st }}$ and $2^{\text {nd }}$ seasons, respectively. Results are in agreement with Abdelhafez et al. (2016), they indicated that hand weeding method was more effective for controlling weeds when compared to unweeding and chemical herbicides. This may led to a positive effect on yield per hectare.

\subsection{Effect of the interaction between nitrogen fertilizer rates and weed control methods}

The interaction between mineral nitrogen $\left(535.71 \mathrm{~kg} \mathrm{~N} \mathrm{ha}^{-1}\right)$ and hand weeding method had significantly increased yield ha ${ }^{-1}$ than the other interaction treatments in both growing seasons (Table 2). The increases in yield due to application of the highest rate of nitrogen and hand weeding 
method were about 193.47 and $222.43 \%$ over control treatment (unfertilized and unweeding plants) in the $1^{\text {st }}$ and $2^{\text {nd }}$ seasons, respectively. The obtained results may suggest that even at high growth of weeds, the high $\mathrm{N}$ application protects the growing plants from the nutrient deficiency. Furthermore, Lee et al. (2011) found that fertilizer level of $120 \mathrm{~kg} \mathrm{~N} \mathrm{ha}^{-1}$ produced as much onion bulb yield as higher $\mathrm{N}$ levels (240 and $360 \mathrm{~kg} \mathrm{~N}$ ha $\left.{ }^{1}\right)$.

\section{Characteristics of bulb}

\subsection{Percentages of marketable and non-marketable yield components \\ 2.1.1. Effect of nitrogen fertilizer rates}

In general, marketable yield was more than non-marketable yield of onion plants. In addition, the highest values of marketable yield and the lowest values of non-marketable yield were recorded with application of mineral nitrogen fertilizer at the highest rate $\left(535.71 \mathrm{~kg} \mathrm{~N} \mathrm{ha}^{-1}\right)$ by using hand weeding method in both growing seasons (Abdelhafez et al., 2016).

For marketable yield, fertilization of onion plants under newly reclaimed soil with the highest rate of mineral nitrogen $\left(535.71 \mathrm{~kg} \mathrm{~N} \mathrm{ha}^{-1}\right)$ had significantly decreased percentage of bulbs ranged from $3.5-6 \mathrm{~cm}$ in diameter than other nitrogen rates or unfertilized plants (control). The lowest values of bulbs ranged from $3.5-6 \mathrm{~cm}$ in diameter were recorded with the highest rate of nitrogen in both growing seasons. On the other hand, percentage of bulbs ranged from $6-8 \mathrm{~cm}$ in diameter and increased significantly at the highest rate of mineral nitrogen $\left(535.71 \mathrm{~kg} \mathrm{~N} \mathrm{ha}^{-1}\right)$ than other nitrogen rates or unfertilized plants (control). The highest values of bulbs ranged from $6-8 \mathrm{~cm}$ in diameter were recorded with the highest rate of nitrogen in both growing seasons (Table 3).

For non-marketable yield, fertilization of onion plants under newly reclaimed soil with the highest rate of mineral nitrogen $\left(535.71 \mathrm{~kg} \mathrm{~N} \mathrm{ha}^{-1}\right)$ had significantly decreased percentages of bolters and pickles than other nitrogen rates or unfertilized plants (control). The lowest values of bolters and pickles were recorded with the highest rate of nitrogen in both growing seasons (Table 3). This could be associated with the effect of nitrogen in extending the vegetative growth period of plants while delaying flowering. These results are in harmony with these recorded by Yamasaki and Tanaka (2005), who reported that low nitrogen promoted bolting in onion (Allium fistulosum L.) and induced flowers to emerge before bulbs that were adequately developed to suppress flower initiation (Roberts et al., 1997). Abdissa et al. (2011) reported that nitrogen fertilization significantly reduced bolting in onion by 11 and $22 \%$ in response to applications of nitrogen at rates of 69 and $92 \mathrm{~kg} \mathrm{~N} \mathrm{ha}^{-1}$, respectively. Also, Gebretsadik (2016) found that increasing nitrogen from nil to $150 \mathrm{~kg} \mathrm{~N}^{-1}$ decreased bolting percentage by $62 \%$. On the other hand, percentage of doubles increased 
significantly at the highest rate of mineral nitrogen $\left(535.71 \mathrm{~kg} \mathrm{~N} \mathrm{ha}^{-1}\right)$ than other nitrogen rates or unfertilized plants (control) and the highest values of doubles were recorded with the highest rate of nitrogen in both growing seasons. Similar results reported that the percent of double bulbs increased significantly with increasing the rate of NPK fertilizers (Yaso and AbdelRazzak, 2007), especially $\mathrm{N}$ enhanced the percentage of marketable doubles up to $200 \mathrm{~kg} \mathrm{~N} \mathrm{ha}^{-1}$ in both seasons of study (Al-Fraihat, 2009).

\subsubsection{Effect of weed control methods}

For marketable yield, using hand weeding method decreasing percentage of bulbs ranged from 3.5-6 cm in diameter than using other weed control methods. The lowest values of bulbs ranged from $3.5-6 \mathrm{~cm}$ in diameter were recorded with hand weeding method in both growing seasons. On the other hand, percentage of bulbs ranged from $6-8 \mathrm{~cm}$ in diameter increased significantly by using hand weeding method than using other weed control methods. The highest values of bulbs ranged from $6-8 \mathrm{~cm}$ in diameter were recorded with hand weeding method in both growing seasons (Table 3).

For non-marketable yield, using hand weeding method decreased percentages of bolters and pickles than using other weed control methods. The lowest values of bolters and pickles were recorded with hand weeding method in both growing seasons. On the other hand, percentage of doubles increased significantly by using hand weeding method than using other weed control methods. The highest values of doubles were recorded with hand weeding method in both growing seasons (Table 3).

These results are in agreement with a previous work conducted by Abdelhafez et al. (2016), who indicated that hand weeding method was more effective for increasing marketable yield and decreasing non-marketable yield of onion plants. In this concern, Uygur et al. (2010) found that weedfree check caused $76.3 \%$ increase in the onion yield when compared with weedy checks.

\subsubsection{Effect of the interaction between nitrogen fertilizer rates and weed control methods}

For marketable yield, the interaction between mineral nitrogen (535.71 $\mathrm{kg} \mathrm{N} \mathrm{ha}{ }^{-1}$ ) and hand weeding method had significantly decreased percentage of bulbs ranged from 3.5-6 $\mathrm{cm}$ in diameter than the other interaction treatments and the lowest values of bulbs ranged from $3.5-6 \mathrm{~cm}$ in diameter were recorded with application of the highest rate of nitrogen and hand weeding method in both growing seasons. On the other hand, the interaction between mineral nitrogen (535.71 $\mathrm{kg} \mathrm{N} \mathrm{ha}^{-1}$ ) and hand weeding method had significantly increased percentage of bulbs ranged from $6-8 \mathrm{~cm}$ in diameter than the other interaction treatments. The highest values of bulbs ranged from $6-8 \mathrm{~cm}$ in diameter were recorded with application of the highest rate of nitrogen and hand weeding method in both growing seasons (Table 3 ). 
Table (3). Percentages of marketable and non-marketable yield components of onion plants as affected by nitrogen fertilizer rates, weed control methods and their interaction between them during $2014 / 2015$ and $2015 / 2016$ seasons.

\begin{tabular}{|c|c|c|c|c|c|c|c|c|}
\hline \multirow[b]{2}{*}{ Treatments } & \multicolumn{4}{|c|}{ 2014/2015 season } & \multicolumn{4}{|c|}{ 2015/2016 season } \\
\hline & P0 & P1 & P2 & Mean & P0 & P1 & P2 & Mean \\
\hline \multicolumn{9}{|c|}{ Marketable yield } \\
\hline \multicolumn{9}{|c|}{ Bulbs ranged from $3.5-6 \mathrm{~cm}$ in diameter $(\%)$} \\
\hline No & $84.91 \mathrm{a}$ & $46.36 \mathrm{e}$ & $36.22 \mathrm{f}$ & $55.83 \mathrm{a}$ & $70.68 \mathrm{a}$ & $33.26 \mathrm{e}$ & $30.58 \mathrm{f}$ & $44.84 \mathrm{a}$ \\
\hline N1 & $71.76 \mathrm{~b}$ & $31.43 \mathrm{~g}$ & $28.71 \mathrm{~h}$ & $43.97 b$ & $65.51 \mathrm{~b}$ & $24.94 \mathrm{~g}$ & $22.38 \mathrm{~h}$ & $37.61 \mathrm{~b}$ \\
\hline N2 & $64.11 \mathrm{c}$ & $22.38 \mathrm{i}$ & $19.91 \mathrm{j}$ & $35.47 \mathrm{c}$ & $51.46 \mathrm{c}$ & $18.63 \mathrm{i}$ & $14.89 \mathrm{j}$ & $28.33 \mathrm{c}$ \\
\hline N3 & $47.51 \mathrm{~d}$ & $16.15 \mathrm{k}$ & 12.241 & $25.30 \mathrm{~d}$ & $38.92 \mathrm{~d}$ & $11.66 \mathrm{k}$ & 7.821 & $19.47 \mathrm{~d}$ \\
\hline Mean & $67.07 \mathrm{a}$ & $29.08 \mathrm{~b}$ & $24.27 \mathrm{c}$ & & $56.64 \mathrm{a}$ & $22.12 b$ & $18.92 \mathrm{c}$ & \\
\hline \multicolumn{9}{|c|}{ Bulbs ranged from $6-8 \mathrm{~cm}$ in diameter $(\%)$} \\
\hline No & 15.091 & $53.64 \mathrm{~h}$ & $63.78 \mathrm{~g}$ & $44.17 \mathrm{~d}$ & 29.321 & $66.74 \mathrm{~h}$ & $69.42 \mathrm{~g}$ & $55.16 \mathrm{~d}$ \\
\hline N1 & $28.24 \mathrm{k}$ & $68.57 \mathrm{f}$ & $71.29 \mathrm{e}$ & $56.03 \mathrm{c}$ & $34.49 \mathrm{k}$ & $75.06 \mathrm{f}$ & $77.62 \mathrm{e}$ & $62.39 \mathrm{c}$ \\
\hline $\mathbf{N 2}$ & $35.89 \mathrm{j}$ & $77.62 \mathrm{~d}$ & $80.09 \mathrm{c}$ & $64.53 b$ & $48.54 j$ & $81.37 \mathrm{~d}$ & $85.11 \mathrm{c}$ & $71.67 \mathrm{~b}$ \\
\hline N3 & $52.49 \mathrm{i}$ & $83.85 \mathrm{~b}$ & $87.76 \mathrm{a}$ & $74.70 \mathrm{a}$ & $61.08 \mathrm{i}$ & $88.34 b$ & $92.18 \mathrm{a}$ & $80.53 \mathrm{a}$ \\
\hline Mean & $32.93 \mathrm{c}$ & $70.92 b$ & $75.73 \mathrm{a}$ & & $43.36 c$ & $77.88 \mathrm{~b}$ & $81.08 \mathrm{a}$ & \\
\hline \multicolumn{9}{|c|}{ Non-marketable yield } \\
\hline \multicolumn{9}{|c|}{ Doubles (\%) } \\
\hline No & 2.871 & $21.13 \mathrm{~h}$ & $25.97 \mathrm{~g}$ & $16.66 \mathrm{~d}$ & 5.221 & $25.26 \mathrm{~h}$ & $30.24 \mathrm{~g}$ & $20.24 d$ \\
\hline N1 & $8.24 \mathrm{k}$ & $34.14 \mathrm{f}$ & $37.94 \mathrm{e}$ & $26.77 \mathrm{c}$ & $10.43 \mathrm{k}$ & $35.41 \mathrm{f}$ & $39.37 \mathrm{e}$ & $28.40 \mathrm{c}$ \\
\hline N2 & $12.73 \mathrm{j}$ & $43.42 \mathrm{~d}$ & $48.64 \mathrm{c}$ & $34.93 b$ & $15.34 \mathrm{j}$ & $46.34 \mathrm{~d}$ & $50.47 \mathrm{c}$ & $37.38 \mathrm{~b}$ \\
\hline N3 & $14.15 \mathrm{i}$ & $56.48 \mathrm{~b}$ & $64.26 \mathrm{a}$ & $44.96 \mathrm{a}$ & $20.46 \mathrm{i}$ & $59.39 \mathrm{~b}$ & $70.17 \mathrm{a}$ & $50.01 \mathrm{a}$ \\
\hline Mean & $9.50 \mathrm{c}$ & $38.79 \mathrm{~b}$ & $44.20 \mathrm{a}$ & & $12.86 \mathrm{c}$ & $41.60 \mathrm{~b}$ & $47.56 \mathrm{a}$ & \\
\hline \multicolumn{9}{|c|}{ Bolters (\%) } \\
\hline No & $38.88 \mathrm{a}$ & $28.89 \mathrm{e}$ & $26.18 \mathrm{f}$ & $31.32 \mathrm{a}$ & $38.15 \mathrm{a}$ & $28.42 \mathrm{e}$ & $25.47 \mathrm{f}$ & $30.68 \mathrm{a}$ \\
\hline N1 & $35.34 \mathrm{~b}$ & $21.17 \mathrm{~g}$ & $19.95 \mathrm{~h}$ & $25.49 b$ & $35.36 \mathrm{~b}$ & $22.24 \mathrm{~g}$ & $19.45 \mathrm{~h}$ & $25.68 \mathrm{~b}$ \\
\hline N2 & $33.63 \mathrm{c}$ & $17.00 \mathrm{i}$ & $15.12 \mathrm{j}$ & $21.92 \mathrm{c}$ & $32.32 \mathrm{c}$ & $17.50 \mathrm{i}$ & $15.26 \mathrm{j}$ & $21.69 \mathrm{c}$ \\
\hline N3 & $32.81 \mathrm{~d}$ & $12.71 \mathrm{k}$ & 10.861 & $18.79 \mathrm{~d}$ & $30.43 d$ & $12.17 \mathrm{k}$ & 9.351 & $17.32 \mathrm{~d}$ \\
\hline Mean & $35.16 \mathrm{a}$ & $19.94 b$ & $18.03 \mathrm{c}$ & & $34.06 \mathrm{a}$ & $20.08 \mathrm{~b}$ & $17.38 \mathrm{c}$ & \\
\hline \multicolumn{9}{|c|}{ Pickles (\%) } \\
\hline No & $58.25 \mathrm{a}$ & $49.98 \mathrm{e}$ & $47.85 f$ & $52.03 a$ & $56.63 a$ & $46.32 \mathrm{e}$ & $44.29 f$ & $49.08 \mathrm{a}$ \\
\hline N1 & $56.42 b$ & $44.69 \mathrm{~g}$ & $42.11 \mathrm{~h}$ & $47.74 b$ & $54.21 \mathrm{~b}$ & $42.35 \mathrm{~g}$ & $41.18 \mathrm{~h}$ & $45.91 \mathrm{~b}$ \\
\hline N2 & $53.64 \mathrm{c}$ & $39.58 \mathrm{i}$ & $36.24 \mathrm{j}$ & $43.15 c$ & $52.34 \mathrm{c}$ & $36.16 \mathrm{i}$ & $34.27 \mathrm{j}$ & $40.92 c$ \\
\hline $\mathbf{N 3}$ & $53.04 d$ & $30.81 \mathrm{k}$ & 24.881 & $36.24 d$ & $49.11 d$ & $28.44 \mathrm{k}$ & 20.481 & $32.68 \mathrm{~d}$ \\
\hline Mean & $55.34 \mathrm{a}$ & $41.26 \mathrm{~b}$ & $37.77 \mathrm{c}$ & & $53.07 \mathrm{a}$ & $38.32 b$ & $35.05 \mathrm{c}$ & \\
\hline
\end{tabular}

Means with the same letters are not significantly differed at $5 \%$ according to Duncan's multiple range test.

$\mathrm{N} 0=0 \mathrm{~kg} \mathrm{~N} \mathrm{ha}{ }^{-1} \& \mathrm{~N} 1=178.60 \mathrm{~kg} \mathrm{~N} \mathrm{ha}^{-1} \& \mathrm{~N} 2=357.14 \mathrm{~kg} \mathrm{~N} \mathrm{ha}^{-1} \& \mathrm{~N} 3=535.71$

$\mathrm{kg} \mathrm{N} \mathrm{ha}^{-1}$.

P0 $=$ Unweeded \& P1 = Chemical herbicides \& P2 = Hand weeding 
For non-marketable yield, the interaction between mineral nitrogen (535.71 kg N ha ${ }^{-1}$ ) and hand weeding method had significantly decreased percentages of bolters and pickles than the other interaction treatments. The lowest values of bolters and pickles were recorded with application of the highest rate of nitrogen and hand weeding method in both growing seasons. On the other hand, the interaction between mineral nitrogen $(535.71 \mathrm{~kg} \mathrm{~N}$ ha${ }^{1}$ ) and hand weeding method had significantly increased percentage doubles than the other interaction treatments. The highest values of doubles were recorded with application of the highest rate of nitrogen and hand weeding method in both growing seasons (Table 3 ).

These results are in agreement with a previous study conducted by Abdelhafez et al. (2016), who indicated that enhancement of yield, increasing marketable yield and decreasing non-marketable yield of onion could be attributed to the increased levels of nitrogen and the use of hand weeding method.

\subsection{Characteristics of fresh bulb}

\subsubsection{Effect of nitrogen fertilizer rates}

Data in table (4) show that there were significant differences between nitrogen fertilizer rates for bulb fresh weight, bulb net weight, bulb diameter and length and bulb dry matter in both growing seasons. Fertilizing onion plants under newly reclaimed soil with the highest rate of mineral nitrogen (535.71 $\mathrm{kg} \mathrm{N} \mathrm{ha}^{-1}$ ) significantly increased bulb fresh weight, bulb net weight, bulb diameter and length and bulb dry matter than other nitrogen rates or unfertilized plants (control) in both growing seasons. The highest values of bulb fresh weight, bulb net weight, bulb diameter and length and bulb dry matter were recorded with the highest rate of nitrogen fertilizer in both growing seasons. This might be attributed to the important role of nitrogen for enhancing chlorophyll contents, enzymes and protein synthesis (ElDesuki et al., 2006a and b). These results are in harmony with those recorded by Aliyu et al. (2007), Sam Ruban (2007), Soleymani and Shahrajabian (2012) and El-Hadidi et al. (2016).

\subsubsection{Effect of weed control methods}

Hand weeding method recorded maximized bulb fresh weight, bulb net weight, bulb diameter and length and bulb dry matter than using other weed control methods. The highest values of bulb fresh weight, bulb net weight, bulb diameter and length and bulb dry matter were recorded with hand weeding method in both growing seasons (Table 4). These results may be due to that hand weeding method had a positive effect on yield of onion plants as compared to unweeding and chemical herbicides (Abdelhafez et al., 2016).

Egyptian J. Desert Res., 68, No. 1, 117-133 (2018) 
Table (4). Characteristics of fresh bulb of onion plants as affected by nitrogen fertilizer rates, weed control methods and their interaction between them during 2014/2015 and 2015/2016 seasons.

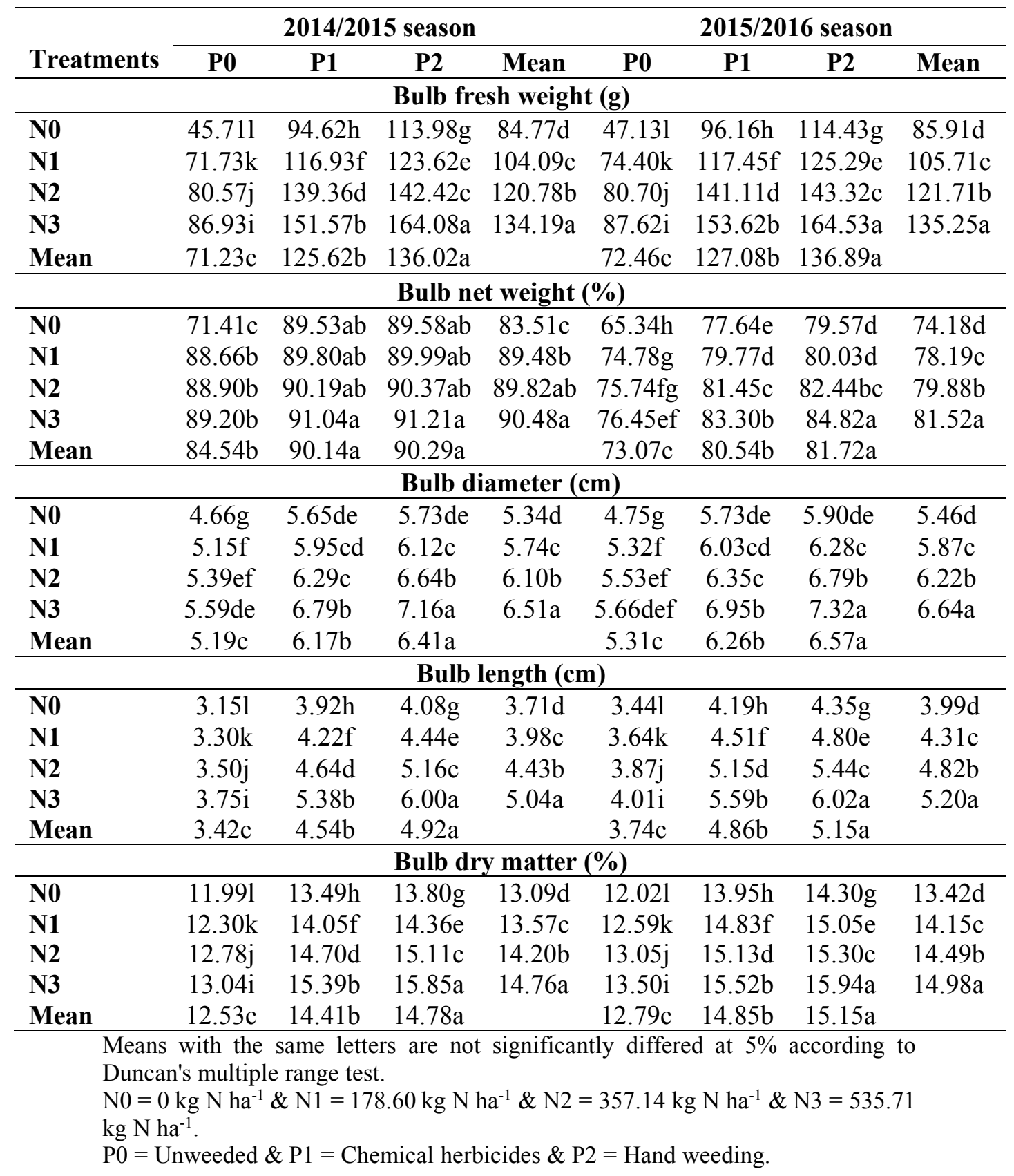




\subsubsection{Effect of the interaction between nitrogen fertilizer rates and weed control methods}

The interaction between mineral nitrogen $\left(535.71 \mathrm{~kg} \mathrm{~N} \mathrm{ha}^{-1}\right)$ and hand weeding method had significantly increased bulb fresh weight, bulb net weight, bulb diameter and length and bulb dry matter than the other interaction treatments in both growing seasons. The highest values of bulb fresh weight, bulb net weight, bulb diameter and length and bulb dry matter were recorded with application of the highest rate of nitrogen and hand weeding method in both growing seasons (Table 4). These results may be due to that enhancement of vegetation growth and yield of onion plants could be attributed to increasing the rate of mineral nitrogen fertilizer and using of hand weeding method (Abdelhafez et al., 2016).

\section{Bulb Quality}

\subsection{Effect of nitrogen fertilizer rates}

Data in table (5) show that fertilizing onion plants under newly reclaimed soil with the highest rate of mineral nitrogen $\left(535.71 \mathrm{~kg} \mathrm{~N} \mathrm{ha}^{-1}\right)$ significantly increased vitamin $\mathrm{C}$ concentration, percentages of sulfur volatile oil, total soluble solids (TSS), crude protein and total carbohydrates of onion bulb than other nitrogen fertilizer rates or unfertilized plants (control) in both growing seasons. The highest values of vitamin $\mathrm{C}$ concentration, percentages of sulfur volatile oil, TSS, crude protein and total carbohydrates of onion bulb were recorded with the highest rate of nitrogen fertilizer in both growing seasons.

These results are in agreement with the previous studies recorded by El-Hadidi et al. (2016), which showed that protein percentage and sulfur volatile oil percentage in onion bulbs after 90 days from transplanting (at harvest stage) was significantly increased as a result of increasing nitrogen fertilizer levels from 0 to 566.9 and $850.0 \mathrm{~kg} \mathrm{~N} \mathrm{ha}^{-1}$.

\subsection{Effect of weed control methods}

Hand weeding method maximized vitamin C concentration, percentages of sulfur volatile oil, TSS, crude protein and total carbohydrates of onion bulb than using other weed control methods. The highest values of vitamin C concentration, percentages of sulfur volatile oil, TSS, crude protein and total carbohydrates of onion bulb were recorded with hand weeding method in both growing seasons (Table 5). These results may be due to that the adoption of hand weeding method for controlling weeds growth significantly enhanced the growing plant for nutrients uptake when compared to unweeding and chemical herbicides (Abdelhafez et al., 2016). 
Table (5). Quality of onion bulb as affected by nitrogen fertilizer rates, weed control methods and their interaction between them during 2014/ 2015 and 2015/2016 seasons.

\begin{tabular}{|c|c|c|c|c|c|c|c|c|}
\hline \multirow[b]{2}{*}{ Treatments } & \multicolumn{4}{|c|}{ 2014/2015 season } & \multicolumn{4}{|c|}{ 2015/2016 season } \\
\hline & P0 & P1 & P2 & Mean & P0 & P1 & P2 & Mean \\
\hline \multicolumn{9}{|c|}{ Vitamin $\mathrm{C}(\mathrm{mg} / 100 \mathrm{~g}$ fresh weight $)$} \\
\hline No & 15.721 & $18.18 \mathrm{~h}$ & $18.55 \mathrm{~g}$ & $17.48 \mathrm{~d}$ & 16.141 & $18.29 \mathrm{~h}$ & $57 \mathrm{~g}$ & $17.67 \mathrm{~d}$ \\
\hline N1 & $.97 \mathrm{k}$ & $18.57 \mathrm{f}$ & $18.73 \mathrm{e}$ & $17.76 \mathrm{c}$ & $16.21 \mathrm{k}$ & $18.94 \mathrm{f}$ & $98 \mathrm{e}$ & $18.04 \mathrm{c}$ \\
\hline N2 & $16.17 \mathrm{j}$ & $19.17 \mathrm{~d}$ & $20.03 c$ & $18.45 \mathrm{~b}$ & $16.62 \mathrm{j}$ & $19.24 d$ & $20.06 \mathrm{c}$ & $18.64 \mathrm{~b}$ \\
\hline N3 & $17.14 \mathrm{i}$ & $20.07 \mathrm{~b}$ & $20.45 \mathrm{a}$ & $19.22 \mathrm{a}$ & $17.89 \mathrm{i}$ & $20.08 b$ & $20.48 \mathrm{a}$ & $19.48 \mathrm{a}$ \\
\hline Mean & $16.25 \mathrm{c}$ & $18.99 \mathrm{~b}$ & $19.44 \mathrm{a}$ & & $16.72 \mathrm{c}$ & $19.14 \mathrm{~b}$ & $19.52 \mathrm{a}$ & \\
\hline \multicolumn{9}{|c|}{ Sulfur volatile oil (\%) } \\
\hline No & & $\mathrm{h}$ & $1.68 \mathrm{~g}$ & $1.47 \mathrm{~d}$ & 1.121 & & & 1.49 \\
\hline N1 & & & & & & $2.19 \mathrm{f}$ & & $1.84 \mathrm{c}$ \\
\hline $\mathbf{N} 2$ & & 2.2 & 2.6 & & & $2.26 \mathrm{~d}$ & $2.68 \mathrm{c}$ & $2.04 \mathrm{~b}$ \\
\hline N3 & $58 \mathrm{i}$ & $2.73 b$ & $2.76 \mathrm{a}$ & $2.36 \mathrm{a}$ & $60 \mathrm{i}$ & $2.74 \mathrm{~b}$ & $2.79 \mathrm{a}$ & $2.37 \mathrm{a}$ \\
\hline Me & $24 c$ & $2.18 \mathrm{~b}$ & $2.32 \mathrm{a}$ & & $1.26 \mathrm{c}$ & $2.20 \mathrm{~b}$ & $2.34 \mathrm{a}$ & \\
\hline \multicolumn{9}{|c|}{ Total soluble solids (TSS) \% } \\
\hline No & .081 & $13.13 \mathrm{~h}$ & $13.39 \mathrm{~g}$ & $12.87 \mathrm{~d}$ & $12.52 \mathrm{i}$ & $13.65 \mathrm{f}$ & $13.74 \mathrm{f}$ & $13.30 \mathrm{~d}$ \\
\hline N1 & $.17 \mathrm{k}$ & $14.21 \mathrm{f}$ & $14.40 \mathrm{e}$ & $13.59 \mathrm{c}$ & $12.62 \mathrm{hi}$ & $14.56 \mathrm{e}$ & $14.77 \mathrm{~d}$ & $13.98 \mathrm{c}$ \\
\hline $\mathbf{N} 2$ & $12.29 \mathrm{j}$ & $15.21 \mathrm{~d}$ & $15.40 \mathrm{c}$ & $14.30 \mathrm{~b}$ & $12.71 \mathrm{~h}$ & $15.63 \mathrm{c}$ & $15.75 \mathrm{c}$ & $14.70 \mathrm{~b}$ \\
\hline N3 & $12.40 \mathrm{i}$ & $16.21 \mathrm{~b}$ & $16.38 \mathrm{a}$ & $15.00 \mathrm{a}$ & $12.88 \mathrm{~g}$ & $16.58 b$ & $16.75 \mathrm{a}$ & $15.40 \mathrm{a}$ \\
\hline & & & $14.89 \mathrm{a}$ & & $12.68 \mathrm{c}$ & $15.10 \mathrm{~b}$ & $15.25 \mathrm{a}$ & \\
\hline \multicolumn{9}{|c|}{ Crude protein (\%) } \\
\hline No & $9 \mathrm{k}$ & $7.34 \mathrm{j}$ & & & 7.561 & $7.66 \mathrm{k}$ & $7.84 j$ & $7.69 \mathrm{~d}$ \\
\hline N1 & & & & & & $3 \mathrm{~h}$ & $47 \mathrm{~g}$ & $11.93 \mathrm{c}$ \\
\hline $\mathbf{N} 2$ & $7 \mathrm{f}$ & 13 & & & & $13.87 \mathrm{e}$ & $26 \mathrm{~d}$ & $13.92 b$ \\
\hline $\mathbf{N}^{2}$ & $66 \mathrm{c}$ & $14.90 \mathrm{~b}$ & $15.23 \mathrm{a}$ & $14.93 \mathrm{a}$ & $14.67 \mathrm{c}$ & $15.03 \mathrm{~b}$ & $15.70 \mathrm{a}$ & $15.13 \mathrm{a}$ \\
\hline $\mathbf{N}$ & $58 \mathrm{c}$ & $11.80 \mathrm{~b}$ & $12.23 \mathrm{a}$ & & $11.84 \mathrm{c}$ & $12.10 \mathrm{~b}$ & $12.57 \mathrm{a}$ & \\
\hline \multicolumn{9}{|c|}{ Total carbohydrates (\%) } \\
\hline $\mathbf{N}$ & 361 & $15.40 \mathrm{~h}$ & $15.58 \mathrm{~g}$ & & 14.421 & $15.56 \mathrm{~h}$ & $80 \mathrm{~g}$ & 15.26 \\
\hline $\mathbf{N}$ & $46 \mathrm{k}$ & $16.42 \mathrm{f}$ & $16.64 \mathrm{e}$ & 15. & $14.55 \mathrm{k}$ & $16.44 \mathrm{f}$ & $16.71 \mathrm{e}$ & $15.90 \mathrm{c}$ \\
\hline $\mathbf{N}_{2}^{2}$ & $60 \mathrm{j}$ & $17.42 \mathrm{~d}$ & $17.58 \mathrm{c}$ & $16.53 b$ & $14.68 \mathrm{j}$ & $17.45 d$ & $17.70 \mathrm{c}$ & $16.61 \mathrm{~b}$ \\
\hline N3 & li & $18.52 b$ & $18.75 \mathrm{a}$ & $17.32 \mathrm{a}$ & $14.83 \mathrm{i}$ & $18.55 b$ & $18.85 \mathrm{a}$ & $17.41 \mathrm{a}$ \\
\hline Mean & $14.53 \mathrm{c}$ & $16.94 b$ & $17.14 \mathrm{a}$ & & $14.62 \mathrm{c}$ & $17.00 \mathrm{~b}$ & $17.26 \mathrm{a}$ & \\
\hline
\end{tabular}

Means with the same letters are not significantly differed at 5\% according to Duncan's multiple range test.

$\mathrm{N} 0=0 \mathrm{~kg} \mathrm{~N} \mathrm{ha}^{-1} \& \mathrm{~N} 1=178.60 \mathrm{~kg} \mathrm{~N} \mathrm{ha}^{-1} \& \mathrm{~N} 2=357.14 \mathrm{~kg} \mathrm{~N}^{-1} \& \mathrm{~N} 3=535.71$ $\mathrm{kg} \mathrm{N} \mathrm{ha}^{-1}$.

P0 $=$ Unweeded \& P1 $=$ Chemical herbicides \& P2 $=$ Hand weeding. 


\subsection{Effect of the interaction between nitrogen fertilizer rates and weed control methods}

The interaction between mineral nitrogen $\left(535.71 \mathrm{~kg} \mathrm{~N} \mathrm{ha}^{-1}\right)$ and hand weeding method had significantly increased vitamin $\mathrm{C}$ concentration, percentages of sulfur volatile oil, TSS, crude protein and total carbohydrates of onion bulb than the other interaction treatments in both growing seasons. The highest values of vitamin $C$ concentration, percentages of sulfur volatile oil, TSS, crude protein and total carbohydrates of onion bulb were recorded with application of the highest rate of nitrogen fertilizer and hand weeding method in both growing seasons (Table 5).

\section{CONCLUSION}

It could be concluded that, under the New Valley Governorate conditions, fertilizing onion plants cv. Giza 6 with $535.71 \mathrm{~kg} \mathrm{~N} \mathrm{ha}^{-1}$ and using hand weeding method were the best treatments for increasing yield and bulb quality.

\section{REFERENCES}

A.O.A.C. Association of Official Analytical Chemists (2000). In "Official Methods of Analysis". 17 th $^{\text {th }}$ ed., A.O.A.C. International, Maryland, USA.

Abbey, L. and D.C. Joyce (2004). Water deficit stress and soil type effects on spring onion growth. Journal of Vegetable Crop Production, 10 (2): 5-18.

Abdelhafez, A.A., M.A.M. Ali, A.I. El-Tokhy and M.E. Amer (2016). Effects of nitrogen and herbicides on onion production in a newly reclaimed soil and their potential health risks. Egyptian J. Desert Res., 66 (1): 115-136.

Abdel-Mawgoud, A.R., S.R. Abou-Hussein and M.A. El-Nemr (2005). Interactive effects of zinc and different nitrogen sources on yield and quality of onion. Arab-Universities J. Agric. Sci., 13 (3): 863-875.

Abdissa, Y., T. Tekalign and L.M. Pant (2011). Growth, bulb yield and quality of onion (Allium cepa L.) as influenced by nitrogen and phosphorus fertilization on vertisol I. growth attributes, biomass production and bulb yield. African J. Agric. Res., 6 (14): 3252-3258.

Albero, B., C.S. Brunte and J.L. Tadeo (2001). Multiresidue determination of pesticides in honey by matrix solid-phase dispersion and gas chromatography with electron-capture detection. Journal of AOAC International, 84 (4): 1165-1171.

Al-Fraihat, A.H. (2009). Effect of different nitrogen and sulphur fertilizer levels on growth, yield and quality of onion (Allium cepa L.). Jordan J. Agric. Sci., 5 (2): 155-166.

Egyptian J. Desert Res., 68, No. 1, 117-133 (2018) 
Aliyu, U., M.D. Magaji, A. Singh and S.G. Mohammed (2007). Growth and yield of onion (Allium cepa L.) as influenced by nitrogen and phosphorus levels. Int. J. Agri. Res., 2 (11): 937-944.

Bungard, R.A., A. Wingler, J.D. Morton and M. Andrews (1999). Ammonium can stimulate nitrate and nitrite reductase in the absence of nitrate in Clematis vitalba. Plant Cell Environment, 22 (7): 859866.

Duncan, D.B. (1958). Multiple range and multiple F test. Biometrics, 11: 142.

El-Desuki, M., A.R. Mahmoud and M.M. Hafiz (2006a). Response of onion plants to minerals and bio-fertilizers application. Res. J. Agric. Biol. Sci., 2 (6): 292-298.

El-Desuki, M., M.M. Abdel-Mouty and A.H. Ali (2006b). Response of onion plants to additional dose of potassium application. J. Appl. Sci. Res., 2 (9): 592-597.

El-Hadidi, E.M., M.M. El-Shazly and Heba M.M. Hegazy (2016). Effect of $\mathrm{N}, \mathrm{P}$ and $\mathrm{CU}$ fertilization on onion yield, quality and nutrients uptake. J. Soil Sci. and Agric. Eng., Mansoura Univ., 7 (2): 231-236.

El-Hamady, M.M. (2017). Growth and yield of onion Allium cepa L. as influenced by nitrogen and phosphorus fertilizers levels. Canadian J. Agric. Crops., 2 (1): 34-41.

FAOSTAT (2015). Food and Agriculture Organization of the United Nations. Available online: http://www.fao.org/faostat/en/\#data/QC

Gebretsadik, K. (2016). Agronomic and economic evaluation of nitrogen fertilizer rates and intra row spacing on growth and bulb yield of onion (Allium cepa L.) under rainfall condition. Journal of Biology, Agriculture and Healthcare, 6 (21): 1-10.

Hedge, J.E. and B.T. Hofreiter (1962). In 'Carbohydrate Chemistry 17' (Whistler R.L. and J.N. Be Miller Eds.). Academic Press, New York.

Khan, A.A., M. Zubair, A. Bari and F. Maula (2007). Response of onion (Allium cepa) growth and yield to different levels of nitrogen and zinc in swat valley. Sarhad J. Agric., 23 (4): 933-936.

Lee, J., J. Moon, H. Kim, I. Ha and S. Lee (2011). Reduced nitrogen, phosphorus, and potassium rates for intermediate-day onion in paddy soil with incorporated rice straw plus manure. HortScience, 46 (3): 470-474.

Marschner, H. (1995). In "Mineral Nutrition of Higher Plants". Academic Press, San Diego, U.S.A.

Martinez, M.C., V. Corzo and M. Villamiel (2007). Biological properties of onions and garlic. Trends Food Sci. Tech., 18 (12): 609-625.

Nasreen, S., M.M. Haque, M.A. Hossain and A.T.M. Farid (2007). Nutrient uptake and yield of onion as influenced by nitrogen and sulphur fertilization. Bangladesh J. Agric. Res., 32 (3): 413-420. 
Ramalingam, S.P., C. Chinnagounder, M. Perumal and M.A. Palanisamy (2013). Evaluation of new formulation of oxyfluorfen $(23.5 \% \mathrm{EC})$ for weed control efficacy and bulb yield in onion. American Journal of Plant Sciences, 4 (4): 890-895.

Rizk, F.A. (1997). Productivity of onion plant (Allium cepa L.) as affected by method of planting and NPK application. Egypt. J. Hort., 24 (2): 219-238.

Rizk, F.A., A.M. Shaheen, E.H. Abd El-Samad and Omaima M. Sawan (2012). Effect of different nitrogen plus phosphorus and sulphur fertilizer levels on growth, yield and quality of onion (Allium cepa L.). J. Appl. Sci. Res., 8 (7): 3353-3361.

Roberts, E.H., R.J. Summer field, R.H. Ellis, P.Q. Craufurd and T.R. Wheeler (1997). In "The Induction of Flowering". The Physiology of Vegetable Crops. (Wien, H.C. Ed.). CAB Intl., Ithaca. N.Y., p. 69-99.

Sam Ruban, J. (2007). Effect of biofertilizer on seed yielding capacity of onion (Allium cepa Linn.). Plant Archives, 7 (1): 255-256.

Snedecor, G.W. and W.G. Cochran (1980). In "Statistical Methods" $7^{\text {th }}$ ed., Iowa State Univ. Press, Ames, Iowa, USA, pp. 507.

Soleymani, A. and M.H. Shahrajabian (2012). Effects of different levels of nitrogen on yield and nitrate content of four spring onion genotypes. Int. J. Agric. Crop Sci., 4 (4): 179-182.

Stajner, D., R. Igic, B.M. Popovic and D. Malencic (2008). Comparative study of antioxidant properties of wild growing and cultivated Allium species. Phytotherapy Res., 22 (1): 113-117.

Tiwori, R.S., A. Ankur and S.C. Sengar (2002). Effect of doses and methods of nitrogen application on growth, bulb yield and quality of "Pusa Red" onion (Allium cepa). Indian J. Agric. Sci., 72 (1): 23-25.

Uygur, S., R. Gürbüz and F.N. Uygur (2010). Weeds of onion fields and effects of some herbicides on weeds in Cukurova region, Turkey. Afr. J. Biotechnol., 9 (42): 7037-7042.

Yamasaki, A. and K. Tanaka (2005). Effect of nitrogen on bolting of bunching onion (Allium fistulosum L). Hort. Res. (Japan), 4 (1): 5154.

Yaso, I.A. and H.S. Abdel-Razzak (2007). Effect of NPK fertilization on bulb yield and quality of onion under reclaimed calcareous soil conditions. J. Agric. Env. Sci. Alex. Univ., Egypt, 6 (1): 225-244. 


\section{تأثير التسميد النيتروجيني وبعض طرق مكافحة الحشائش على محصول وجودة البصل في الأرض المستصلحة حلئًا}

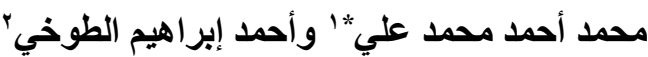

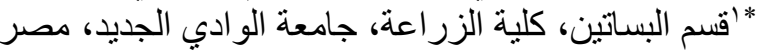

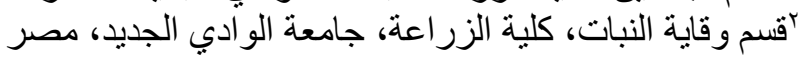

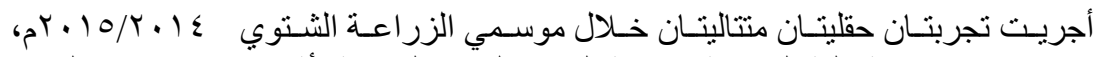

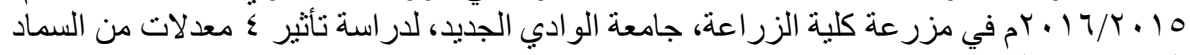

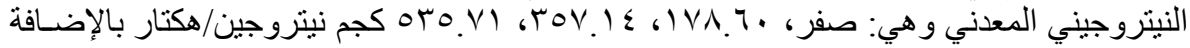

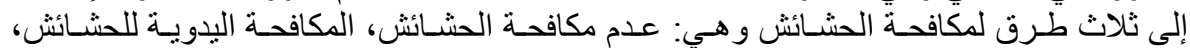

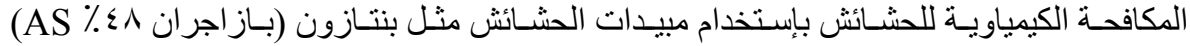

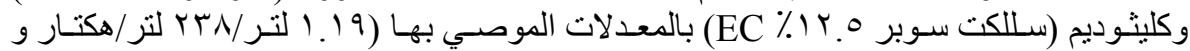

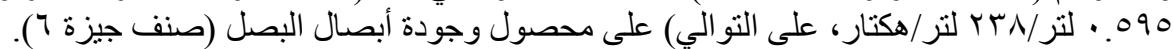

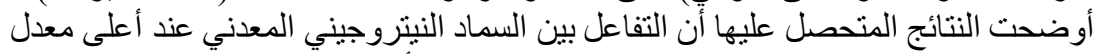

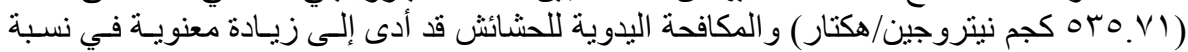

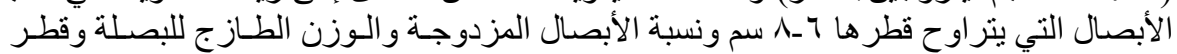

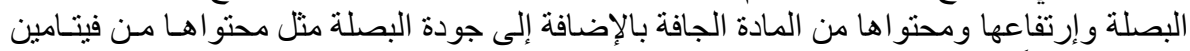

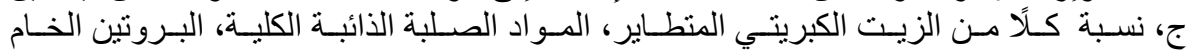
والكربو هيدرات الكلية في الأبصال.

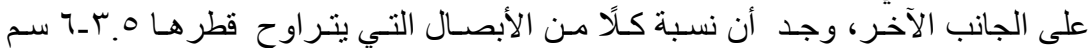

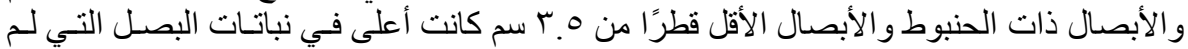

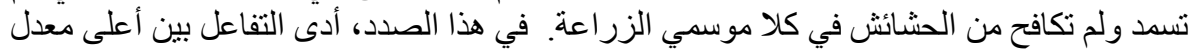

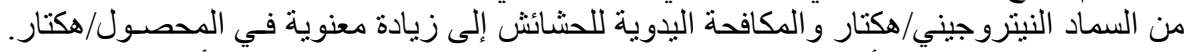

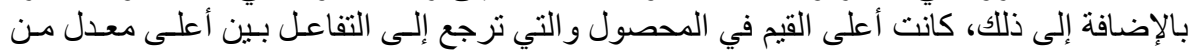

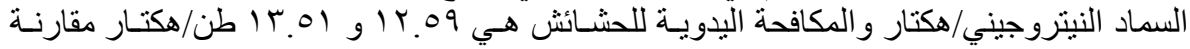

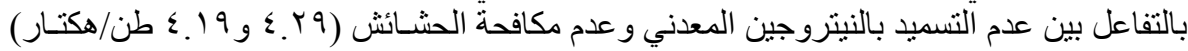
في كلا موسمي الزر اعة، على النو الي. 